\title{
A Synthesis and Review of Medicinal uses, Phytochemistry and Pharmacological Properties of Maerua crassifolia Forssk. (Capparaceae)
}

\author{
Alfred Maroyi ${ }^{*}$
}

Department of Botany, University of Fort Hare, Private Bag X1314, Alice 5700, South Africa

\begin{abstract}
Maerua crassifolia Forssk. is an evergreen tree widely used as traditional medicine throughout its distributional range in the Sahel region, peninsular Arabia east to Pakistan, east and west Africa. This study is aimed at providing a critical review of medicinal uses, phytochemical and pharmacological properties of $M$. crassifolia. Documented information on medicinal uses, phytochemical and pharmacological properties of $M$. crassifolia was collected from several online sources such as Scopus, Google Scholar, PubMed and Science Direct, and pre-electronic sources such as book chapters, books, journal articles and scientific publications obtained from the university library. The articles published between 1964 and 2020 were used in this study. This study revealed that the bark, fruit, leaf and twig infusion and/or decoction of $M$. crassifolia are mainly used as ethnoveterinary medicine, and traditional medicine for cephalalgia, headache, fever, malaria, wounds, skin infections, toothache and gastro-intestinal problems. Phytochemical compounds identified from the species include alkaloids, amino acids, betaines, cardiac glycosides, fatty acids, flavonoids, lignan glucosides, phenolics, quaternary ammonium compounds, saponins, steroids, tannins and terpenoids. The $M$. crassifolia extracts exhibited antibacterial, anti-diarrhoeal, analgesic, anti-inflammatory, antioxidant, antiplasmodial, antiprotozoal, antitrypanosomal, antipyretic and cytotoxicity activities. Maerua crassifolia should be subjected to detailed phytochemical, pharmacological and toxicological evaluations aimed at correlating its medicinal uses with its phytochemistry and pharmacological activities.
\end{abstract}

Keywords: Capparaceae, ethnopharmacology, indigenous knowledge, Maerua crassifolia, traditional medicine.

\section{INTRODUCTION}

Maerua crassifolia Forssk. is an evergreen tree belonging to the Capparaceae or caper family. The synonyms of $M$. crassifolia include $M$. hirtella Chiov., $M$. meyeri-johannis Gilg, M. rigida $\mathrm{R}$. Br., M. uguenensis Gilg and M. uniflora Vahl. [1,2]. Maerua crassifolia is a small, spreading and much-branched tree growing up to ten metres in height $[3,4]$. The bole of the species is stunted and twisted with smooth bark and scaly on older trunks. The leaves are alternate on young twigs and clustered on older branchlets, simple and entire, oblanceolate to elliptic in shape. The flowers are axillary and solitary, borne in terminal spikes or clusters. The fruit is brown in colour, oblong or cylindrical capsule, that is irregularly constricted between the seeds. Maerua crassifolia has been recorded in the Sahel region, peninsular Arabia east to Pakistan, east and west Africa [5-10]. The species has been recorded in dry savanna, deciduous bushland, thickets and semi-desert scrub near rivers at an altitude ranging from sea level to $1620 \mathrm{~m}$ above sea level [4]. Maerua crassifolia is one of the important medicinal plants in tropical Africa and the species is included in the book "plant resources of tropical Africa 11(2):

*Address correspondence to this author at the Department of Botany, University of Fort Hare, Private Bag X1314, Alice 5700, South Africa

Tel/Fax: 0027719600326; E-mail: amaroyi@ufh.ac.za medicinal plants 2", a photographic guide to the most commonly used traditional medicines in tropical Africa [11]. The species is also used beyond its natural distributional range. For example, the Senegalese migrants living in Turin, Italy use the twigs of $M$. crassifolia against halitosis [12]. The bark of $M$. crassifolia is widely used in the Sahel region to purify and reduce the turbidity of water $[3,13]$. The leaves of M. crassifolia are consumed as a leafy vegetable in Burkina Faso, Chad, Ethiopia, Kenya, Mali, Mauritania, Niger and Nigeria and Sudan [14-24]. The flowers and fruits of $M$. crassifolia are consumed in Algeria and the Sahel region $[4,16,25]$, and the species is also important for bee forage in Oman [26]. The fresh and dried leaves of $M$. crassifolia are traded locally in the Sahel region [4]. The leaves and shoots of $M$. crassifolia are browsed by wild and domesticated animals in Kenya and the Sahel region [27-32]. The roots, shoots and stems of $M$. crassifolia are used as toothbrushes in the Sahel region, particularly in Morocco and Algeria [3,4,16,33,34]. Maerua crassifolia is an important plant species in the Sahel region and the species could be used in land rehabilitation programmes in degraded landscapes in the region $[35,36]$. It is, therefore, within this context that this review was undertaken aimed at reviewing the medicinal uses, phytochemical and pharmacological properties of $M$. crassifolia so as to provide baseline

() 2020 SET Publisher 
data required in evaluating the therapeutic potential of the species.

\section{Medicinal uses}

The bark, fruit, leaf and twig infusion and/or decoction of $M$. crassifolia are mainly used as ethnoveterinary medicine, and traditional medicine for cephalalgia, headache, fever, malaria, wounds, skin infections, toothache and gastro-intestinal problems (Table 1; Figure 1). Other medicinal applications that are recorded in at least two countries and supported by at least two literature records include the use of bark, fruit, leaf and twig infusion and/or decoction as protective charm and purgative, and traditional medicine for abdominal pain, diabetes, jaundice and respiratory problems (Table 1 ). In Mali, the leaf ash of

Table 1: Medicinal uses of Maerua crassifolia

\begin{tabular}{|c|c|c|c|}
\hline Medicinal use & Part used & Country & Reference \\
\hline Abdominal pain & Leaves & Mali and Mauritania & {$[37,38]$} \\
\hline Abdominal pain & $\begin{array}{l}\text { Leaf ash mixed with fruits of Capsicum } \\
\text { annuum L. and Cuminum cyminum L. }\end{array}$ & Mali & [37] \\
\hline Appetite loss & $\begin{array}{c}\text { Leaf ash mixed with fruits of } C \text {. annuum } \\
\text { and } C \text {. cyminum }\end{array}$ & Mali & [37] \\
\hline Cephalalgia and headache & Bark and leaves & Algeria, Egypt and Morocco & {$[33,40,43,44]$} \\
\hline Colic & Leaves & Oman & {$[41,42]$} \\
\hline Diabetes & Leaves & Morocco & [45] \\
\hline Diabetes & $\begin{array}{l}\text { Leaves mixed with gum of Senegalia } \\
\text { senegal (L.) Britton }\end{array}$ & Mauritania & [38] \\
\hline Fever and malaria & Bark and leaves & $\begin{array}{l}\text { Algeria, Egypt, Nigeria, } \\
\text { Oman, Saudi Arabia and } \\
\text { Sudan }\end{array}$ & $\begin{array}{c}{[3,4,13,23,25,33,40,43,4} \\
6-48]\end{array}$ \\
\hline Fever and malaria & $\begin{array}{l}\text { Leaf ash mixed with fruits of } C \text {. annuum } \\
\text { and } C \text {. cyminum }\end{array}$ & Mali & [37] \\
\hline Malaria & $\begin{array}{l}\text { Leaves mixed with those of Hibiscus } \\
\text { sabdariffa L. }\end{array}$ & Mali & [37] \\
\hline Fracture & $\begin{array}{c}\text { Leaves mixed with those of Lawsonia } \\
\text { inermis L. }\end{array}$ & Oman & [39-42] \\
\hline $\begin{array}{l}\text { Gastro-intestinal problems } \\
\text { (constipation, diarrhoea, epigastric, } \\
\text { gastralgia, indigestion and stomach } \\
\text { complaints) }\end{array}$ & Bark, fruits, leaves and twigs & $\begin{array}{l}\text { Algeria, Egypt, Ghana, Mali, } \\
\text { Mauritania, Morocco, Nigeria, } \\
\text { Oman and Saudi Arabia }\end{array}$ & $\begin{array}{c}{[3,4,23,33,37,38,40-} \\
44,49-52]\end{array}$ \\
\hline Halitosis & Twigs & Italy & [12] \\
\hline Heart diseases & Leaves & Mali & [37] \\
\hline Jaundice & Fruits and leaves & Mali and Mauritania & {$[4,37,38]$} \\
\hline Lipido & Bark and leaves & Tanzania & [53] \\
\hline Poor memory & Leaves & Senegal & [12] \\
\hline $\begin{array}{l}\text { Protective charm (good luck and } \\
\text { protection against witchcraft) }\end{array}$ & Twigs & Egypt and Kenya & {$[14,54]$} \\
\hline Purgative & Leaves & Algeria and Morocco & {$[3,4,25,33,44]$} \\
\hline $\begin{array}{l}\text { Respiratory problems (asthma and } \\
\text { colds) }\end{array}$ & Leaves & Mali and Mauritania & {$[37,38]$} \\
\hline Rheumatism & Bark and leaves & Morocco and Sudan & {$[52,55]$} \\
\hline Scorpion stings & Fruits and leaves & Algeria & [25] \\
\hline $\begin{array}{l}\text { Skin infections (boils, burns, infected } \\
\text { hairy skins, itching and scalp care) }\end{array}$ & Bark and leaves & Egypt, Morocco and Nigeria & {$[4,13,23,34,40,43,44,52]$} \\
\hline Tetanus & Leaves & Senegal & [12] \\
\hline Toothache & Bark and leaves & $\begin{array}{l}\text { Algeria, Egypt, Mauritania, } \\
\text { Morocco and Saudi Arabia }\end{array}$ & $\begin{array}{l}{[13,25,33,38,40,43,50-} \\
52]\end{array}$ \\
\hline Wounds & Bark, leaves and stems & Egypt, Morocco and Sudan & {$[4,34,39,40,44,52,56]$} \\
\hline $\begin{array}{c}\text { Ethnoveterinary medicine } \\
\text { (diarrhoea, eye problems, ticks and } \\
\text { wounds) }\end{array}$ & Bark and leaves & $\begin{array}{c}\text { Ethiopia, Kenya, Morocco and } \\
\text { Niger }\end{array}$ & {$[4,57,58]$} \\
\hline
\end{tabular}




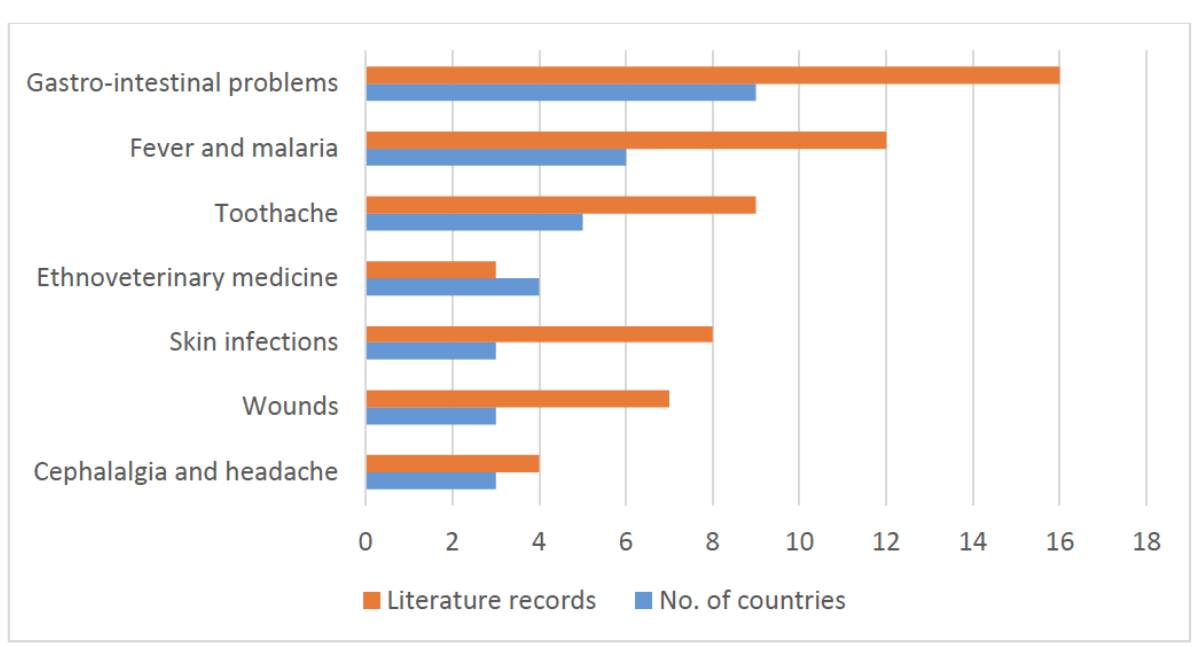

Figure 1: Medicinal applications of Maerua crassifolia derived from literature records.

M. crassifolia is mixed with fruits of Capsicum annuum L. and Cuminum cyminum L. as traditional medicines for abdominal pain, appetite loss, fever and malaria [37]. Diallo et al. [37] also argued that the leaves of $M$. crassifolia are mixed with those of Hibiscus sabdariffa L. as herbal medicine for malaria. In Mauritania, the leaves of $M$. crassifolia are mixed with the gum of Senegalia senegal (L.) Britton as traditional medicine for diabetes [38]. In Oman, a paste made from the powdered leaves of $M$. crassifolia and those of Lawsonia inermis L., which is placed on the fractured bone to reduce pain [39-42].

\section{Nutritional and Phytochemistry}

Some researchers identified nutritional elements and phytochemical compounds from the aerial parts and leaves of $M$. crassifolia and these include alkaloids, amino acids, betaines, fatty acids, flavonoids, lignan glucosides, phenolics, tannins, nutritional compounds, quaternary ammonium compounds, minor and major elements (Table 2). Other phytochemical compounds identified from the leaves of $M$. crassifolia include cardiac glycosides, phenols, resins, saponins, steroids and terpenoids [59-61].

\section{Pharmacological Properties}

The following pharmacological activities have been documented from the aerial parts, leaves and stems of M. crassifolia: antibacterial, anti-diarrhoeal, analgesic, anti-inflammatory, antioxidant, antiplasmodial, antiprotozoal, antitrypanosomal, antipyretic and cytotoxicity activities.

\section{Antibacterial Activities}

Abdel-Sattar et al. [69] evaluated the antibacterial activities of the methanol extract of $\mathrm{M}$. crassifolia aerial parts against Escherichia coli, Proteus vulgaris, Pseudomonas aeruginosa, Staphylococcus aureus, Sarcina lutea, Bacillus subtilis and Mycobacterium phlei using agar-diffusion method with ofoxacine (5.0 $\mu \mathrm{g} / \mathrm{disc}$ ) as positive control. The extract exhibited activities against all tested pathogens with the exception of Mycobacterium phlei, with zone of inhibition ranging from $10.0 \mathrm{~mm}$ to $15.0 \mathrm{~mm}$ [69]. Ckilaka et al. [60] evaluated the antibacterial activities of the methanol leaf extract of M. crassifolia against Staphylococcus aureus, Shigella spp., Salmonella typhi, Bacillus subtilis and Escherichia coli using disc diffusion and broth micro dilution methods. The extract exhibited activities against the tested pathogens with the zone of inhibition ranging from $7.8 \mathrm{~mm}$ to $29.6 \mathrm{~mm}$ while the minimum inhibitory concentration (MIC) and minimum bactericidal concentration (MBC) values ranged from $7.0 \mu \mathrm{g} / \mathrm{ml}$ to $24.0 \mu \mathrm{g} / \mathrm{ml}$ [60].

\section{Anti-Diarrhoeal Activities}

Akuodor et al. [59] evaluated the anti-diarrhoeal activities of the methanol extract of $M$. crassifolia leaves in Wistar albino rats. The extract decreased intestinal propulsion of charcoal meal in rats in a dosedependent manner and the extract produced $100 \%$ inhibition of castor oil-induced diarrhoea [59].

\section{Analgesic Activities}

Akuodor et al. [61] evaluated the analgesic activities of the methanol leaf extract of $M$. crassifolia in Albino mice using the acetic acid-induced writhing and tail immersion methods. The extract at doses of 100.0, 200.0 and $400.0 \mathrm{mg} / \mathrm{kg}$ exhibited dose-dependent inhibition of pain in acetic acid-induced writhing and tail immersion tests [61]. 
Table 2: Nutritional and Phytochemical Composition of Maerua crassifolia

\begin{tabular}{|c|c|c|c|}
\hline Nutritional and chemical compound & Value & Plant part & Reference \\
\hline \multicolumn{4}{|l|}{ Nutritional components } \\
\hline Acid detergent fibre (\%) & 17.0 & Leaves & [29] \\
\hline Acid detergent lignin (\%) & 3.5 & Leaves & [29] \\
\hline Aluminium $(\mu \mathrm{g} / \mathrm{g})$ & 140.0 & Leaves & {$[17]$} \\
\hline Ash (g/100g) & $12.2-13.2$ & Leaves & {$[15,62]$} \\
\hline Carbohydrate (g/100g) & $54.2-64.8$ & Leaves & {$[15,62]$} \\
\hline Chromium $(\mu \mathrm{g} / \mathrm{g})$ & $1.5-5.2$ & Leaves & {$[17,18]$} \\
\hline Copper $(\mu \mathrm{g} / \mathrm{g})$ & $0.2-3.9$ & Leaves & {$[17,18,62]$} \\
\hline Crude fibre $(g / 100 g)$ & 4.7 & Leaves & [62] \\
\hline Crude lipids (g/100g) & 3.2 & Leaves & [62] \\
\hline Gross energy (kcal) & 358.0 & Leaves & [15] \\
\hline Iron $(\mu \mathrm{g} / \mathrm{g})$ & $180.0-499.0$ & Leaves & {$[17,18]$} \\
\hline Magnesium ( $\mu \mathrm{g} / \mathrm{g})$ & $5710.0-7290$ & Leaves & {$[17,18]$} \\
\hline Manganese $(\mu \mathrm{g} / \mathrm{g})$ & $29.9-110.0$ & Leaves & {$[17,18]$} \\
\hline Moisture (\%) & 62.0 & Leaves & [62] \\
\hline Molybdenum $(\mu \mathrm{g} / \mathrm{g})$ & $5.1-22.3$ & Leaves & {$[17,18]$} \\
\hline Neutral detergent fibre (\%) & 23.1 & Leaves & [29] \\
\hline Nickel $(\mu \mathrm{g} / \mathrm{g})$ & 5.0 & Leaves & [18] \\
\hline Phosphorus $(\mu \mathrm{g} / \mathrm{g})$ & 1430.0 & Leaves & [18] \\
\hline Potassium $(\mu \mathrm{g} / \mathrm{g})$ & 35700.0 & Leaves & [18] \\
\hline \multicolumn{4}{|l|}{ Amino acids } \\
\hline Alanine $(\mathrm{mg} / \mathrm{g})$ & $8.9-23.4$ & Leaves & {$[17,18]$} \\
\hline Arginine $(\mathrm{mg} / \mathrm{g})$ & $9.5-23.9$ & Leaves & {$[17,18]$} \\
\hline Aspartic acid (mg/g) & $11.4-31.3$ & Leaves & {$[17,18]$} \\
\hline Cysteine (mg/g) & $3.6-6.8$ & Leaves & {$[17,18]$} \\
\hline Glutamic acid $(\mathrm{mg} / \mathrm{g})$ & $16.6-41.5$ & Leaves & {$[17,18]$} \\
\hline Glycine (mg/g) & $8.0-19.5$ & Leaves & {$[17,18]$} \\
\hline Histidine (mg/g) & $9.9-154.0$ & Leaves & {$[15,17,18]$} \\
\hline Isoleucine $(\mathrm{mg} / \mathrm{g})$ & $7.5-303.0$ & Leaves & {$[15,17,18]$} \\
\hline Leucine (mg/g) & $13.8-545.0$ & Leaves & {$[15,17,18]$} \\
\hline Lysine (mg/g) & $8.6-420.0$ & Leaves & {$[15,17,18]$} \\
\hline Methionine $(\mathrm{mg} / \mathrm{g})$ & $2.0-5.1$ & Leaves & {$[17,18]$} \\
\hline Phenylalanine $(\mathrm{mg} / \mathrm{g})$ & $10.3-28.2$ & Leaves & {$[17,18]$} \\
\hline Proline (mg/g) & $9.8-23.9$ & Leaves & {$[17,18]$} \\
\hline Serine $(\mathrm{mg} / \mathrm{g})$ & $7.1-19.5$ & Leaves & {$[17,18]$} \\
\hline Threonine $(\mathrm{mg} / \mathrm{g})$ & $5.8-324.0$ & Leaves & {$[15,17,18]$} \\
\hline Tyrosine (mg/g) & $9.3-23.3$ & Leaves & {$[17,18]$} \\
\hline Tryptophan (mg/g) & $8.6-176.0$ & Leaves & {$[15,17,18]$} \\
\hline Valine $(\mathrm{mg} / \mathrm{g})$ & $9.9-373.0$ & Leaves & {$[15,17,18]$} \\
\hline
\end{tabular}


(Table 2). Continued.

\begin{tabular}{|c|c|c|c|}
\hline Nutritional and chemical compound & Value & Plant part & Reference \\
\hline \multicolumn{4}{|l|}{ Fatty acids } \\
\hline Hexadecanoic acid (mg/g) & $2.9-3.2$ & Leaves & {$[17,18]$} \\
\hline Stearic acid (mg/g) & $0.9-1.1$ & Leaves & {$[17,18]$} \\
\hline Oleic acid $(\mathrm{mg} / \mathrm{g})$ & 1.0 & Leaves & {$[17,18]$} \\
\hline Linoleic acid (mg/g) & $1.0-1.3$ & Leaves & {$[17,18]$} \\
\hline a-linolenic acid (mg/g) & $4.4-9.3$ & Leaves & {$[17,18]$} \\
\hline \multicolumn{4}{|l|}{ Betaines } \\
\hline 3-hydroxyprolinebetaine & - & Leaves & [63] \\
\hline Glycinebetaine & - & Leaves & [63] \\
\hline Prolinebetaine & - & Leaves & [63] \\
\hline \multicolumn{4}{|l|}{ Flavonoids } \\
\hline Flavonoids (mg catechin/g of extract) & 15.7 & Leaves & [25] \\
\hline Kaempferol & - & Aerial parts & {$[43]$} \\
\hline Kaempferol-3-O-galactorhamnoside & - & Aerial parts & [43] \\
\hline Quercetin & - & Aerial parts & [43] \\
\hline Quercetin-3-O-arabinopyranoside & - & Aerial parts & {$[43]$} \\
\hline Rutin & - & Aerial parts & [43] \\
\hline \multicolumn{4}{|l|}{ Glucosides } \\
\hline Ionol glucoside & - & Aerial parts & {$[64,65]$} \\
\hline Iyoniresincl-3-O-glucopyranoside & - & Aerial parts & [43] \\
\hline 3-O- $\beta$-D-galactopyranoside & - & Aerial parts & {$[64]$} \\
\hline 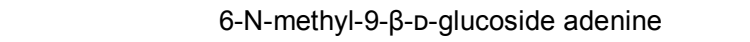 & - & Aerial parts & {$[66]$} \\
\hline 3,4,5-trimethoxyphenol-1-O- $\beta$-D-glucopyranoside & - & Aerial parts & [66] \\
\hline Guaiacyl glycerol & - & Aerial parts & [66] \\
\hline \multicolumn{4}{|l|}{ Lipids and triterpenes } \\
\hline 1,23 dimethoxy tricosa-6-one & - & Aerial parts & [67] \\
\hline Triacontane & - & Aerial parts & [67] \\
\hline Ceryl alcohol & - & Aerial parts & {$[67]$} \\
\hline Lupeol palmitate & - & Aerial parts & [67] \\
\hline$\beta$-sitosterol palmitate & - & Aerial parts & [67] \\
\hline Lupeol acetate & - & Aerial parts & [67] \\
\hline a-amyrin & - & Aerial parts & [67] \\
\hline \multicolumn{4}{|l|}{ Other compounds } \\
\hline 3-hydroxy-1,1-dimethyl prrolidinium & - & Leaves & [63] \\
\hline Stachydrine & - & Aerial parts & {$[43]$} \\
\hline Polyphenol (mg gallic acid/g of extract) & 35.1 & Leaves & {$[25]$} \\
\hline Tannins (mg catechin/g of extract) & 10.2 & Leaves & [25] \\
\hline Trypsin inhibitor ( $\mu \mathrm{g} / \mathrm{mg}$ dry weight) & $3.8-8.2$ & Leaves & [68] \\
\hline
\end{tabular}

\section{Anti-Inflammatory Activities}

Akuodor et al. [61] evaluated the anti-inflammatory activities of the methanol leaf extract of $M$. crassifolia in Albino mice and rats using the xylene and carrageenan-induced paw oedema methods with aspirin $(150.0 \mathrm{mg} / \mathrm{kg})$ and dexamethasone $(4.0 \mathrm{mg} / \mathrm{kg})$ as positive controls. The extract reduced the xyleneinduced ear oedema in mice and the activities exhibited by the extract were comparable to those exhibited by the positive control. On carrageenan-induced paw oedema, the extract exhibited dose-dependent activities and these activities were comparable to those exhibited by the positive control [61].

\section{Antioxidant Activities}

Chaib et al. [25] evaluated the antioxidant activities of the methanol leaf extract of $M$. crassifolia using the 
2,2-diphenyl-1-picrylhydrazyl (DPPH) free radical scavenging assay with ascorbic acid as positive control. The extract exhibited weak activities with half maximal inhibitory concentration $\left(\mathrm{IC}_{50}\right)$ value of 122.9 $\mu \mathrm{g} / \mathrm{ml}$ [25]. Ckilaka et al. [60] evaluated the antioxidant activities of the methanol leaf extract of $M$. crassifolia using the DPPH free radical scavenging assay with ascorbic acid as positive control. The extract exhibited activities with the $\mathrm{IC}_{50}$ value of $58.9 \mu \mathrm{g} / \mathrm{ml}$ in comparison to the $\mathrm{IC}_{50}$ value of $4.8 \mu \mathrm{g} / \mathrm{ml}$ exhibited by the positive control [60].

\section{Antiplasmodial Activities}

Abdel-Sattar et al. [71] evaluated the antiplasmodial activities of methanol extracts of $M$. crassifolia stems against Plasmodium falciparum $\mathrm{GHA}_{-}$-strain using the parasite lactate deshydrogenase as an assay with chloroquine as positive control. The extract exhibited weak activities with the $\mathrm{IC}_{50}$ value of $43.9 \mu \mathrm{g} / \mathrm{ml}$ [71]. Akuodor et al. [70] evaluated the in vivo antiplasmodial activities of methanol leaf extract of $M$. crassifolia in mice infected with chloroquine sensitive Plasmodium berghei berghei at dose levels of 100.0, 200.0 and $400.0 \mathrm{mg} / \mathrm{kg}$ p.o. with chloroquine $(10.0 \mathrm{mg} / \mathrm{kg})$ as the standard drug. The extract exhibited dose-dependent chemo-suppression of the tested parasite of $71.0 \%$, $80.0 \%$ and $86.0 \%$ at doses of $100.0,200.0$ and 400.0 $\mathrm{mg} / \mathrm{kg}$, respectively, in comparison to $93.0 \%$ exhibited by the positive control [70].

\section{Antiprotozoal Activities}

Camacho et al. [47] evaluated the antiprotozoal activities of methanol and aqueous extracts of $M$. crassifolia stems against Leishmania donovani using the antileishmanial assay with the antileishmanial drug pentamidine used as positive control. The methanol and aqueous extracts exhibited weak activities with the $\mathrm{IC}_{50}$ values of $371.5 \mu \mathrm{g} / \mathrm{ml}$ and $>500.0 \mu \mathrm{g} / \mathrm{ml}$, respectively [47]. Abdel-Sattar et al. [71] evaluated the antiprotozoal activities of methanol and aqueous extracts of $M$. crassifolia stems against Leishmania infantum amastigotes using an in vitro antileishmanial assay with miltefosin as a positive control. The extract exhibited weak activities against the tested pathogen with the $\mathrm{IC}_{50}$ value $>64.0 \mu \mathrm{g} / \mathrm{ml}$ [71].

\section{Antitrypanosomal Activities}

Abdel-Sattar et al. [71] evaluated the antitrypanosomal activities of methanol extracts of $M$. crassifolia stems against the trypomastigotes of Trypanosoma brucei brucei squib-427 strain and
Trypanosoma cruzi using the Alamar Blue and an enzyme-linked immunosorbent assay with benznidazole and suramin as positive controls. The extract exhibited weak activities against Trypanosoma brucei brucei and Trypanosoma cruzi with the $\mathrm{IC}_{50}$ values of $33.5 \mu \mathrm{g} / \mathrm{ml}$ and $29.8 \mu \mathrm{g} / \mathrm{ml}$, respectively [71].

\section{Antipyretic Activities}

Akuodor et al. [61] evaluated the antipyretic activities of the methanol leaf extract of $M$. crassifolia in Albino rats using the yeast and amphetamine-induced pyrexia method. The extract exhibited activities by causing a reduction in hyperpyrexia [61].

\section{Cytotoxicity Activities}

Camacho et al. [47] evaluated the cytotoxicity activities of methanol and aqueous extracts of $M$. crassifolia stems using a micro dilution technique against KB cells. The aqueous and methanol extracts exhibited weak activities with $\mathrm{IC}_{50}$ values of 172.8 $\mu \mathrm{g} / \mathrm{ml}$ and $>500.0 \mu \mathrm{g} / \mathrm{ml}$, respectively [47]. Abdel-Sattar et al. [71] evaluated the cytotoxicity activities of methanol extracts of $M$. crassifolia stems against MRC5 cell lines using the colony assay with vinblastine as positive control. The extract exhibited weak activities with half maximal cytotoxicity concentration $\left(\mathrm{CC}_{50}\right)$ value of $>64.0 \mu \mathrm{g} / \mathrm{ml}[71]$.

\section{CONCLUSION}

Research on $M$. crassifolia over the past decades shown that this species is an important food plant in the dry Sahel region and other countries in the savanna biome. The species is currently collected from the wild and previous research showed that $M$. crassifolia has great promise as a source of food, fodder and herbal medicines. Therefore, future research should also focus on evaluating phytochemical, pharmacological and toxicological evaluations of the crude extracts and compounds isolated from the species, aimed at correlating its medicinal uses with its phytochemistry and pharmacological activities.

\section{REFERENCES}

[1] Elfers RA, Grahama DG, Dewolf P. Capparidaceae. In Hubbard CE, Milne-Redhead E (Editors), Flora of Tropical East Africa. London: Crown Agents for Oversea Governments and Administrations; 1964, pp. 1-88.

[2] Edwards $\mathrm{S}$, et al. Flora of Ethiopia and Eritrea 2(1). Addis Ababa: The National Herbarium, Addis Ababa University; 2000.

[3] Von Maydell HJ. Trees and shrubs of the Sahel: Their characteristics and uses. Eschborn: Margraf; 1986. 
[4] Bosch CH. Maerua crassifolia Forssk. In Schmelzer GH, Gurib-Fakim A (Editors), Plant resources of tropical Africa 11(2): Medicinal plants 2. Wageningen: Backhuys Publishers; 2013, pp. 162-163.

[5] Wood JRI. A handbook of the Yemen Flora. Richmond: Royal Botanic Gardens, Kew; 1997.

[6] Boulos L. Flora of Egypt 1. Cairo: Al Hadara Publishing; 1999.

[7] Collenette S. Wildflowers of Saudi Arabia. Riyadh: National Commission for Wildlife Conservation and Development (NCWCD); 1999.

[8] Jongbloed M, Western RA and Boer B. Annotated checklist for plants in the United Arab Emirates. Dubai: Zodiac Publishing; 2000.

[9] Mosti S, Raffaelli M and Tardelli M. Contributions to the flora of central-southern Dhofar (Sultanate of Oman). Webbia 2012; 67: 65-91. https://doi.org/10.1080/00837792.2012.10670909

[10] Darbyshire I, et al. The plants of Sudan and South Sudan. Richmond: Kew publishing, Royal Botanic Gardens, Kew; 2015.

[11] Schmelzer GH, Gurib-Fakim A. Plant resources of tropical Africa 11(2): Medicinal plants 2. Wageningen: Backhuys Publishers; 2013.

[12] Ellena R, Quave CL, Pieroni A. Comparative medical ethnobotany of the Senegalese community living in Turin (northwestern Italy) and in Adeane (southern Senegal). Evidence-Based Compl Alt Med 2012; article ID 604363. https://doi.org/10.1155/2012/604363

[13] Burkill HM. The useful plants of west tropical Africa. Richmond: Royal Botanical Garden, Kew; 1985.

[14] Morgan WTW. Ethnobotany of the Turkana: Use of plants by a pastoral people and their livestock in Kenya. Econ Bot 1981; 35(1): 96-130.

https://doi.org/10.1007/BF02859220

[15] Nordeide MB, Holm H, Oshaug A. Nutrient composition and protein quality of wild gathered foods from Mali. Int J Food Sci Nutr 1994; 45: 275-86. https://doi.org/10.3109/09637489409166168

[16] Labidi D, Garitacelaya J. Atil (Maerua crassifolia), the toothbrush tree for people of the Sahara. Revue For Franç 1997; 49(3): 261-4. https://doi.org/10.4267/2042/5620

[17] Cook JA, et al. Nutrient content of two indigenous plant foods of the Western Sahel: Balanites aegyptiaca and Maerua crassifolia. J Food Comp Analy 1998; 11: 221-30. https://doi.org/10.1006/jfca.1998.0582

[18] Freiberger $C$, et al. Nutrient content of the edible leaves of seven wild plants from Niger. PI Foods Human Nutr 1998; 57-69.

[19] Bourlière F, Howell C. African ecology and human evolution. London: Routledge; 2004.

[20] Pieroni A, Price LL. Eating and healing: Traditional food as medicine. Binghamton: Haworth Press; 2006. https://doi.org/10.1201/9781482293616

[21] Lulekal E, et al. Wild edible plants in Ethiopia: A review on their potential to combat food insecurity. Afrika Focus 2011; 24(2): 71-121.

https://doi.org/10.21825/af.v24i2.4998

[22] Hamidou A, et al. Uses and preferences of woody species in two protected forests of Dan Kada Dodo and Dan Gado in Niger. J Hort For 2015; 7(6): 149-59.

https://doi.org/10.5897/JHF2014.0374

[23] Ayeni MJ, Kayode J, Uchendu OC. Ethno-medicinal survey of leafy vegetables among Igbo and Hausa tribes residents in Ado-Ekiti, Nigeria. J Bot Papers 2016; 1: 8-14.

[24] Ouédraogo $P$, et al. Uses and vulnerability of ligneous species exploited by local population of northern Burkina
Faso in their adaptation strategies to changing environments. Agr Food Sec 2017; 6: 15.

https://doi.org/10.1186/s40066-017-0090-z

[25] Chaib $\mathrm{F}$, et al. Phytochemical investigation and biological activities of some Saharan plants from Hoggar. J Agr Sci 2015; 7(7): 163-73.

https://doi.org/10.5539/jas.v7n7p163

[26] Sajwani A, Farooq SA. Determination of the botanical and geographical origins of honey in northern Oman. Biotech Cons Species Arid Reg 2014; 1(2): 181-92.

[27] Stiles D, Kassam A. An ethnobotanical study of Gabra plant use in Marsabit district, Kenya. J East Afr Nat History Soc Nat Museum 1991; 81: 14-37.

[28] Kuria SG, et al. Indigenous camel mineral supplementation knowledge and practices on Manyatta based camel herds by the Rendille pastoralists of Marsabit district, Kenya. Livest Res Rural Develop 2004; 16: 7.

[29] Calabrò $S$, et al. Nutritional characteristics of forages from Niger. Italian J Animal Sci 2007; 6: 271-4.

[30] Houmey VK, et al. Forage production of a fodder tree Sahelian Maerua crassifolia Forsk. J Appl Biosci. 2012; 59: 4349-57.

[31] Kuria SG, et al. Forage species preferred by camels (Camelus dromedarius) and their nutritional composition in North Eastern Kenya. Livest Res Rural Develop 2012; 24: 145.

[32] Wasonga $\mathrm{O}$, et al. Vegetation resources and their economic importance in Isiolo County, Kenya. London: IIED; 2016.

[33] Hammiche V, Maiza K. Traditional medicine in central Sahara: Pharmacopoeia of Tassili N'ajjer. J Ethnopharmacol 2006; 105: 358-67. https://doi.org/10.1016/j.jep.2005.11.028

[34] Volpato G, Kourková P, Zelený V. Healing war wounds and perfuming exile: the use of vegetal, animal, and mineral products for perfumes, cosmetics, and skin healing among Sahrawi refugees of Western Sahara. J Ethnobiol Ethnomed 2012; 8: 49.

https://doi.org/10.1186/1746-4269-8-49

[35] Lambert JDH, Ryden PA, Esikuri EE. Capitalizing on the bioeconomic value of multi-purpose medicinal plants for the rehabilitation of drylands in sub-Saharan Africa. Washington DC: The International Bank for Reconstruction and Development; 2005.

[36] Patzelt A, et al. The Oman botanic garden (2): Collections policy, nursery construction, expanded plant production and initial tree translocation. Sibbaldia J Bot Garden Hort 2009; 7: 83-97.

[37] Diallo D, et al. An ethnobotanical survey of herbal drugs of Gourma district, Mali. Pharm Biol 1999; 37(1): 80-91. https://doi.org/10.1076/phbi.37.1.80.6313

[38] Yebouk C, et al. Ethnobotanical study of medicinal plants in the Adrar province, Mauritania. J Ethnopharmacol 2020; 246: 112217. https://doi.org/10.1016/j.jep.2019.112217

[39] Boulos L. Medicinal plants of north Africa. Michigan: Reference Publications Inc.; 1983.

[40] Goodin JR, Northington DK. Plant resources of arid and semiarid lands: A global perspective. New York: Academic Press; 1985.

[41] Ghazanfar SA, Al-Sabahi AMA. Medicinal plants of northern and central Oman (Arabia). Econ Bot 1993; 47(1): 89-98. https://doi.org/10.1007/BF02862209

[42] Sakkir S, Kabshawi M, Mehairbi M. Medicinal plants diversity and their conservation status in the United Arab Emirates (UAE). J Med Plants Res 2012; 6(7): 1304-22.

https://doi.org/10.5897/JMPR11.1412

[43] Bishay DW, et al. Phytochemical study of Maerua crassifolia Forssk. growing in Egypt. Bull Pharmaceut Sci Assiut Univ 1990; 13: 39-49. https://doi.org/10.21608/bfsa.1990.70544 
[44] Abouri M, et al. An ethnobotanical survey of medicinal plants used in the Tata province, Morocco. Int $\mathrm{J}$ Med Plant Res 2012; 1(7): 99-123.

[45] Idm'hand E, Msanda F, Cherif K. Ethnopharmacological review of medicinal plants used to manage diabetes in Morocco. Clinical Phytosci 2020; 6: 18. https://doi.org/10.1186/s40816-020-00166-z

[46] El Kamali HM, El Khalifa KF. Treatment of malaria through herbal drugs in the central Sudan. Fitoterapia 1997; 68(6): 527-8.

[47] Camacho MR, et al. Screening of plant extracts for antiprotozoal and cytotoxic activities. J Ethnopharmacol 2003; 89: 185-91. https://doi.org/10.1016/S0378-8741(03)00269-1

[48] Ramadan MA, et al. Phytochemical study of Maerua crassifolia Forssk. growing in Egypt. Bull Pharmaceut Sci Assiut Univ 1990; 13: 39-49. https://doi.org/10.21608/bfsa.1990.70544

[49] Irvine FR. Woody plants of Ghana, with special reference to their uses. Oxford: Oxford University Press; 1961.

[50] Mossa JS, Al-Yahya MA, Al-Meshal IA. Medicinal plants of Saudi Arabia. Riyadh: King Saud University Press; 2000.

[51] El-shabasy A. Survey on medicinal plants in the flora of Jizan region, Saudi Arabia. Int J Bot Stud 2016; 2(1): 38-59.

[52] Idm'hand E, Msanda F, Cherif K. Ethnobotanical study and biodiversity of medicinal plants used in the Tarfaya province, Morocco. Acta Ecol Sinica 2020; 40: 134-44. https://doi.org/10.1016/j.chnaes.2020.01.002

[53] Njau EA. An ethnobotanical study of medicinal plants used by the Maasai people of Many Ara-Arusha, Tanzania. MSc Dissertation. Addis Ababa: Addis Ababa University; 2001.

[54] Mahmoud T, Gairola S. Traditional knowledge and use of medicinal plants in the Eastern Desert of Egypt: A case study from Wadi El-Gemal National Park. J Med Plants Stud 2013; 1(6): 10-17.

[55] Khalid $\mathrm{H}$, et al. Gems from traditional north-African medicine: Medicinal and aromatic plants from Sudan. Nat Prod Bioprospect 2012; 2: 92-103. https://doi.org/10.1007/s13659-012-0015-2

[56] Doka IG, Yagi SM. Ethnobotanical survey of medicinal plants in west Kordofan (western Sudan). Ethnobot Leafl 2009; 13: 1409-16.

[57] Antoine-Moussiaux N, Faye B,-Vias GF. Tuareg ethnoveterinary treatments of camel diseases in Agadez area (Niger). Trop Anim Health Prod 2007; 39: 83-9. https://doi.org/10.1007/s11250-007-4404-1

[58] Volpato G, Saleh SML, Nardo AD. Ethnoveterinary of Sahrawi pastoralists of Western Sahara: camel diseases and remedies. J Ethnobiol Ethnomed 2015; 11: 54. https://doi.org/10.1186/s13002-015-0040-4
[59] Akuodor GC, et al. Phytochemical and anti-diarrhoeal properties of methanolic leaf extract of Maerua crassifolia Forssk. European J Med Plants 2014; 4(10): 1223-31. https://doi.org/10.9734/EJMP/2014/11246

[60] Ckilaka KC, et al. Antibacterial and antioxidant activities of methanolic leaf extract of Maerua crassifolia. J Appl Pharmaceut Sci 2015; 5(10): 147-50. https://doi.org/10.7324/JAPS.2015.501025

[61] Akuodor GC, Analgesic, antiinflammatory and antipyretic activities of methanolic leaf extract of Maerua crassifolia. J Coastal Life Med 2016; 4(3): 225-30.

[62] Aletan UI, Kwazo HA. Analysis of the proximate composition, anti-nutrients and mineral content of Maerua crassifolia leaves. Nigerian J Basic Appl Sci 2019; 27(1): 89-96. https://doi.org/10.4314/njbas.v27i1.12

[63] McLean WHF, Blunden G, Jewers K. Quaternary ammonium compounds in the Capparaeae. Biochem Syst Ecol 1996; 24: 427-34. https://doi.org/10.1016/0305-1978(96)00044-0

[64] Ibraheim ZZ. A new ionol glucoside from Maerua crassifolia Forssk. grown in Egypt. Bull Pharmaceut Sci Assiut Univ 1995; 18: 27-31.

https://doi.org/10.21608/bfsa.1995.69669

[65] Rahman MA, et al. New ionol glycosides from Maerua crassifolia Forssk grown in Egypt. Bull Pharmaceut Sci Assiut Univ 1998; 21: 89-95. https://doi.org/10.21608/bfsa.1998.67956

[66] Rahman MA, et al. Minor constituents from Maerua crassifolia Forssk growing in Egypt. Bull Pharmaceut Sci Assiut Univ 1999; 22: 109-16. https://doi.org/10.21608/bfsa.1999.66087

[67] Ibraheim ZZ, Ahmed AS, Ramadan MA. Lipids and triterpenes from Maerua crassifolia growing in Egypt. Saudi Pharmaceut J 2008; 16: 69-74.

[68] Vanderjagt DJ, et al. The trypsin inhibitor content of 61 wild edible plant foods of Niger. PI Foods Human Nutr 2000; 55: 335-46.

https://doi.org/10.1023/A:1008136100545

[69] Abdel-Sattar E, Harraz FM, El Gayed SH. Antimicrobial activity of extracts of some plants collected from the Kingdom of Saudi Arabia. J King Abdulaziz Univ Med Sci 2008; 15(1): 25-33.

https://doi.org/10.4197/Med.15-1.3

[70] Akuodor GC, et al. Antimalarial potency of the methanol leaf extract of Maerua crassifolia Forssk (Capparaceae). Asian Pacific J Trop Dis 2014; 4(1): 35-9. https://doi.org/10.1016/S2222-1808(14)60310-8

[71] Abdel-Sattar E, Maes L, Salama MM. In vitro activities of plant extracts from Saudi Arabia against malaria, leishmaniasis, sleeping sickness and Chagas disease. Phytoth Res 2010; 24: 1322-1328.

https://doi.org/10.1002/ptr.3108

DOI: https://doi.org/10.29169/1927-5951.2020.10.05.2

(C) 2020 Alfred Maroyi; Licensee SET Publisher.

This is an open access article licensed under the terms of the Creative Commons Attribution Non-Commercial License (http://creativecommons.org/licenses/by-nc/3.0/) which permits unrestricted, non-commercial use, distribution and reproduction in any medium, provided the work is properly cited. 